\title{
Bioaccumulation of Plant Nutrients by Euryale ferox Salisb. Growing in Field Condition in Northern Bihar of North India
}

\author{
Amit Kumar ${ }^{1}$, I. S. Singh ${ }^{2 *}$, A. K. Thakur², A. K. Choudhary ${ }^{3}$, Vidyanath Jha ${ }^{6}$, \\ S. P. Singh ${ }^{4}$, S. S. Prasad ${ }^{4}$, Pankaj Yadav ${ }^{5}$ and Ramesh Kumar ${ }^{1}$ \\ ${ }^{1}$ Department of Biotechnology, LNMU, Darbhanga, Bihar, India \\ ${ }^{2}$ ICAR Research Complex for Eastern Region, Research Centre for Makhana, \\ Darbhanga-846005, India \\ ${ }^{3}$ ICAR Research Complex for Eastern Region, Patna, Bihar, India \\ ${ }^{4}$ Department of Soil Science, Rajendra Agricultural University, Pusa, Bihar, India \\ ${ }^{5}$ Shri Bhola Paswan Shastri Agricultural College, Purnia, BAU, sabour, Bihar, India \\ ${ }^{6}$ Department of Botany, MRM College, LNMU, Darbhanga, Bihar, India \\ *Corresponding author
}

\begin{tabular}{|c|c|}
\hline & A B S T R A C T \\
\hline & \multirow{4}{*}{$\begin{array}{l}\text { E. ferox an aquatic plant requires a rich soil, preferably growing in still water. It } \\
\text { prefers tropical and sub-tropical climate. In general, aquatic plants take up large } \\
\text { quantities of nutrients and metals from environment, releasing them when they } \\
\text { decay. They also differ both in their capacity to take up nutrient elements in root } \\
\text { tissues and in the proportion of nutrient transferred to above ground parts. With } \\
\text { this view, nutrient elements concentrations in different parts of the E. ferox and } \\
\text { their contribution to the soil system were studied. The study showed that E. ferox } \\
\text { tended to have highest tissue concentrations of } \mathrm{N} \text { and } \mathrm{P} \text { in the leaf parts while the } \\
\text { less soluble Fe, Mn and intermediately soluble } \mathrm{Zn} \text { exhibited greater concentrations } \\
\text { in roots than in shoots. Thus, E. ferox can also be proved to be a better option as } \\
\text { an alternative crop to include it in cropping system mode under field condition to } \\
\text { replenish the exhausted nutrients such as } \mathrm{N}, \mathrm{P} \text { and } \mathrm{Zn} \text { by the cultivation of other } \\
\text { cereal crops. }\end{array}$} \\
\hline $\begin{array}{l}\text { Bioaccumulation, } \\
\text { Nutrients, } \\
\text { Absorption, } \\
\text { Euryale ferox, } \\
\text { Nutrient } \\
\text { Contribution, } \\
\text { Waterlogged } \\
\text { condition. }\end{array}$ & \\
\hline Article Info & \\
\hline $\begin{array}{l}\text { Accepted: } \\
\text { 17 June } 2017 \\
\text { Available Online: } \\
10 \text { July } 2017\end{array}$ & \\
\hline
\end{tabular}

\section{Introduction}

The northeastern part of India has chains of rivers, intersected with many tributaries and canals. This has made possible a saucershaped wetland ecosystem bounded by land. Categorically, wetlands are lands transitional between terrestrial and wet areas, where the soil is frequently waterlogged during rainy months the water table is usually at or near the surface or the land is inundated by varying depths of water. Wetlands form the transitional zone between land and water. Saturation with water is the dominant factor, determining the nature of soil developed and the type of the plant and animals communities living on it.

Wetlands within the state of Bihar are attributed mainly to the complex fluvial 
geomorphology of the Gangetic tributaries which have over a period of time created a number of natural depressions and cut-off meanders known variously as mauns, chaurs and taals. These wetlands are a characteristic feature of the inter fluvial regimes of Gangetic plains which are completely inundated during monsoon and remain shallow with a maximum depth of $1.5 \mathrm{~m}$, and mostly dry by March-June. Kabartaal (Begusarai), Kusheshwarsthan (Darbhanga), Baraila (Vaishali), and Motijheel (East Champaran) are some of the major wetlands of the state. Wild rice, Makhana (Euryale ferox), and water chestnut (Trapa bispinosa), and some of the aquatic weeds such as Cyperus spp., Eleocharis sp., Phragmites sp., Hydrilla verticillata, Vallisneria spiralis, Eichhornia crasssipes and Azolla pinnata are some of the main wetland flora that form an integral part of local culture.

The total area of wetlands in India has been estimated to be $15.26 \mathrm{~m}$ ha approximately covering $5 \%$ of national geographic area (Kumar, 2012). The survival of human civilization is inextricably linked with wetlands, which sustain the economic stability of hundreds of millions of people. And this swampy environment of the carboniferous period produced and preserved many of the fossil fuels on which we greatly depend now. Thus James (1995) has rightly termed these areas as Nature's Kidney."

E. ferox is one of the most popular and economically important food crop of north Bihar wetlands. It is an annual floating-leaved herb (with C3 type of photosynthesis) growing in diverse areas from the tropics to the frigid zones, with a great importance to a wide sector of rural people. It is native to Southeast Asia, and prevalent in tropical and subtropical regions with humid to sub-humid environments, like China, Japan, Malaysia, Thailand, the Philippines, Java, Sumatra, Nepal, Bangladesh, Sri Lanka, and India. In
India, it is distributed in West Bengal, Bihar, Manipur, Tripura, Assam, eastern Odisha, Kashmir lakes and Uttar Pradesh. However, its commercial cultivation is limited to north Bihar. In the state of Bihar, major E. ferox producing districts include Darbhanga, Madhubani, Saharsa, Supaul, Araria, Kishanganj, Purnia and Katihar. Approximately, $80 \%$ of total production of processed E. feroxcomes from Darbhanga, Madhubani, Purnia and Katihar districts alone. Area under E. ferox cultivation in Bihar is about 13,000 ha.

From nutritional point of view, E. ferox is considered a superior dry fruit, as it is endowed with several rich nutritional ingredients. The popped E. ferox contain $12.8 \%$ moisture (w/w), $9.7 \%$ protein, $0.4 \%$ fat, crude fiber ( $\%$ by wt) 0.2 , calorific value (k.cals/100 g) 358, amylose $18.2 \%$, phosphorus $53.2 \mathrm{mg} / 100 \mathrm{~g}$, and iron 1.4 $\mathrm{mg} / 100 \mathrm{~g}$ (Kumar et al., 2011). It has high essential amino acid index (Jha et al., 1991a, b).

Besides the production of food, wetlands are continuously enriched by the addition of large quantities of biomass, and the soil is enriched in consequence. E. ferox is also known to incorporate huge amount of organic matter (610 tonnes/ha) to the soil on account of having large leaf size and extensive root system. Soil organic matter serves as an important store house of nutrients, drives nutrient cycle, improves soil productivity, promotes water retention, and reduces erosion (Bulluck et al., 2002). Under crop cultivation, changes in soil organic matter status would determine the dynamics of alluvial soil quality of wet lands. In addition to makhana, the other component crops also add an appreciable amount of organic matter to soil. Jha and Dutta (2003) had reported the chemical changes in soil under E. ferox plants growing in naturally existing ponds. 
The biomass yield of makhana, growing in ponds in India, was positively correlated with $\mathrm{N}, \mathrm{K}$, and organic $\mathrm{C}$, with the electrical conductivity of the soil, and with the contents of $\mathrm{N}, \mathrm{K}, \mathrm{P}, \mathrm{Na}, \mathrm{Cl}, \mathrm{HCO}^{-1}, \mathrm{Ca}+\mathrm{Mg}$, and $\mathrm{SO}_{4}{ }^{-}$ ${ }^{2}$ (Dutta and Jha, 1984; Dutta et al., 1986). A typical grayish black-to black coloured soil dominated by clay (mucky type) is the main characteristic feature in low-lying areas of this zone. Indeed, organic matter is comparatively high, but, due to anaerobic condition prevailing for many months during wet season, it is partially decomposed. The soil status may further be improved if same period is allowed for quick decaying of such waste materials during post-wet months under aerobic conditions. In this region, one of the most conventional practices by farmers is to utilize this resource-rich humus soil for the succeeding arable crops (rice, potato and wheat) (Mahto and Jha, 1998). The aquatic plants growing in the study area exhibit different macro and micro element concentrations depending on the plant organ and both the sampling time and the sampling sites. Roots of aquatic plants absorb nutrient elements from the sediments and accumulate high concentrations (Baldantoni et al., 2004). It is a novel study and on this aspect, no reference is available particularly on contribution of nutrients by E. ferox crop to the soil.

In the light of above mentioned facts the present study is an evaluation of chemical composition of different organs of E. ferox plants growing in shallow wetland condition in Darbhanga region of northern Bihar.

\section{Materials and Methods}

A field trial was conducted during 01.03.2012 to 30.03.2015 at the research farm of the ICAR-RCER, Regional Research Centre for Makhana, Darbhanga, north Bihar, India, located in the Bagmati flood plain (lat. 26 $10^{\prime}$
$\mathrm{N}$, long. $85^{\circ} 87^{\prime} \mathrm{E}$, elev. $49 \mathrm{~m}$ a.s.l. and mean annual rainfall $1150 \mathrm{~mm}$ ). E. ferox plants were uprooted from the soil, air-dried and ground through Willey crushing machine to pass through a 2-mm sieve. The sieved material was stored for chemical analysis. Plant samples were taken at physiological maturity of $E$. ferox plants for the determination of nitrogen $(\mathrm{N})$, phosphorus $(\mathrm{P})$, potassium $(\mathrm{K})$, iron $(\mathrm{Fe})$, manganese $(\mathrm{Mn})$, copper $(\mathrm{Cu})$ and zinc $(\mathrm{Zn})$ in edible and nonedible parts of the plant. Crop uptake of macronutrients such as $\mathrm{N}, \mathrm{P}$ and $\mathrm{K}$ and micronutrients such as $\mathrm{Fe}, \mathrm{Mn}, \mathrm{Cu}$ and $\mathrm{Zn}$ were estimated by multiplying the dry matter yields (after drying at $70^{\circ} \mathrm{C}$ to constant weight) of the crop with their corresponding nutrient contents. Nutrient contents in plant parts were measured using standard procedures (Jackson, 1973). All nutrient concentrations in plant samples were expressed on a dry weight basis. Mean nutrient concentrations in the plant material of each crop were calculated.

\section{Results and Discussion}

\section{Nutrient absorption by $E$. ferox}

The data on absorption of macro and micro nutrient elements by the different organs of the E. ferox have been depicted in figures 17. The concentration of $\mathrm{N}, \mathrm{P}$ and $\mathrm{K}$ in different vegetative organs of $E$. ferox showed that leaf tissues recorded maximum $\mathrm{N}$ $(0.31 \%)$ followed by root parts $(0.28 \%)$. The lowest $\mathrm{N}$ content $(0.24 \%)$ was recorded in fruit sheath and petiole (Fig. 1) while in case of $\mathrm{P}$ concentration the fruit sheath $(0.50 \%)$ was found to be the highest accumulator organ of the plant (Fig. 2). In particular, for nitrogen and phosphorus, Jha and Dutta (2003) found $\mathrm{N}$ and $\mathrm{P}$ concentrations ranging, respectively, from 0.16 to $0.19 \%$ and 0.16 to $0.57 \%$ in vegetative parts of E. ferox. $\mathrm{N}$ and $\mathrm{P}$ concentrations reported by them are 
comparable to those measured in E. ferox leaves collected from old traditional ponds. By contrast, the concentration of $\mathrm{K}$ was higher in roots $(0.55 \%)$ than in leaves $(040 \%)$. The fruit sheath $(0.28 \%)$ was observed as the lowest accumulator of K (Fig. 3). The low contents of $\mathrm{K}$ in tissues of E. ferox might be attributed to prolonged flooding that resulted in decreased concentration in flooded plants, which is supported by lower transport of $\mathrm{K}$ to shoots under flooding.

Root oxygen deficiency decreases the selectivity of $\mathrm{K}^{+} / \mathrm{Na}^{+}$uptake by roots in favour of $\mathrm{Na}^{+}$and retards the transport of $\mathrm{K}^{+}$ to shoots (Thompson et al., 1989). This change in selectivity of ion uptake may be one of the causes of $\mathrm{Na}$ accumulation in flooded plants (data not shown). Similar results have been reported by Jha and Dutta (2003).

Roots of E. ferox showed a high absorption of plant nutrients from the sediments and accumulation of high concentrations of micronutrients like $\mathrm{Fe}, \mathrm{Mn}, \mathrm{Cu}$ and $\mathrm{Zn}$. This may be attributed to the fact that in flooded soils, soluble $\mathrm{Fe}^{2+}$ and $\mathrm{Mn}^{2+}$ can lead to excessive uptake during prolonged inundation.

Even if shoots and / or leaves of E. ferox were found to accumulate an appreciable quantity of trace elements but lesser ( $\mathrm{Fe}$ and $\mathrm{Mn}$ ) than roots. Similar observations were also made by Qian et al., (1999) who found that most trace elements showed a greater concentration in roots than shoots. $\mathrm{Fe}$ and $\mathrm{Mn}$ concentrations continued to be greater in roots of E. ferox.

The maximum concentration of iron $(\mathrm{Fe})$ (2405 mg/kg) (Fig. 4) and manganese (Mn) $(1050 \mathrm{mg} / \mathrm{kg}$ ) (Fig. 5) were recorded in root parts of the plant while the lowest concentration of $\mathrm{Fe}(1790 \mathrm{mg} / \mathrm{kg})$ and $\mathrm{Mn}$ $(935 \mathrm{mg} / \mathrm{kg})$ were determined in fruit sheath.
The shallow roots and exposed leaves of $E$. ferox may have facilitated higher uptake of these less soluble metals which became concentrated in the aerobic water saturated $E$. ferox tend to be absorbed primarily from upper sediment layers via roots (Spence, 1964). Root oxidation could also have contributed to formation of $\mathrm{Fe}$ plaques which can absorb metals and are associated with divalent cations that can interfere with uptake of elements such as $\mathrm{Na}$ (Mitsch and Gosselink, 2000).Ye et al., (2001) too had reported higher concentration of $\mathrm{Fe}$ in roots compared to shoots of cattail (Typha latifolia) in wetland used to treat coal combustion byproduct leachate. Indeed, high contents of metals (particularly of $\mathrm{Fe}$ and $\mathrm{Mn}$ ) in roots and low concentration in leaves indicate that only a fraction is transferred from roots to the above ground part of the plant.

The leaf tissue of E. ferox was observed to be the highest accumulator of zinc $(105 \mathrm{mg} / \mathrm{kg})$ followed by petiole tissues $(80 \mathrm{mg} / \mathrm{kg}$ ) (Fig. 7). In contrast to $\mathrm{Fe}$ and $\mathrm{Mn}$ absorption the absorption of $\mathrm{Zn}$ metal was found to be higher in shoot than root. This might be attributed to the higher mobility of $\mathrm{Zn}$ in the plant body in comparison to $\mathrm{Fe}$ and $\mathrm{Mn}$. Pertaining to the copper concentration in plant tissues, almost similar/equivalent amount was noticed in different vegetative organs of E. ferox plant (Fig. 6).

This type of uptake pattern confirms the direct adsorption from the water into the shoots or confirms the contribution of water pertaining to translocation of nutrients to the shoot parts of the plant. It is difficult to establish whether, and in what proportion an element is taken up from sediments by the roots of floating plant or from water directly by the shoots; it certainly depends on the chemical behavior of elements and also on sediment geochemistry (Jackson, 1998). 
Fig.1 $\mathrm{N}$ concentrations in different vegetative and seed parts of E. ferox

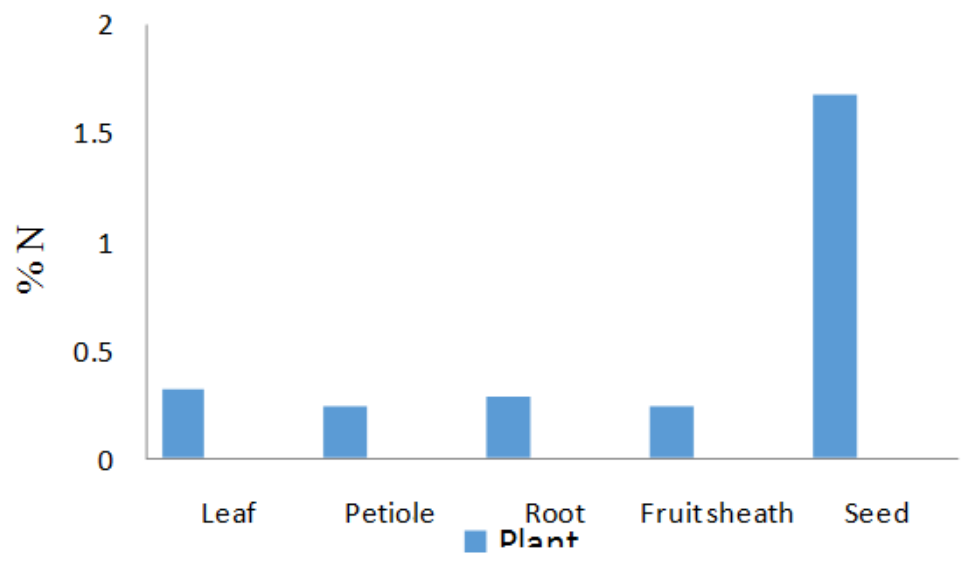

Fig.2 P concentrations in different vegetative and seed parts of E. ferox

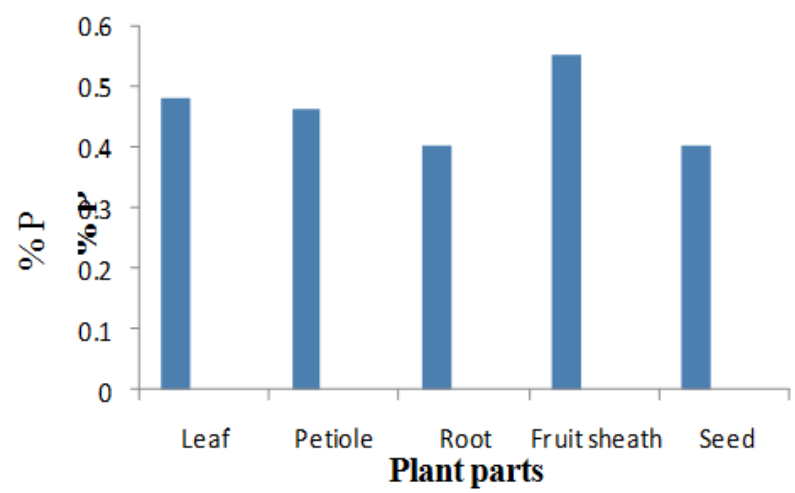

Fig.3 K concentrations in different vegetative and seed parts of E. ferox

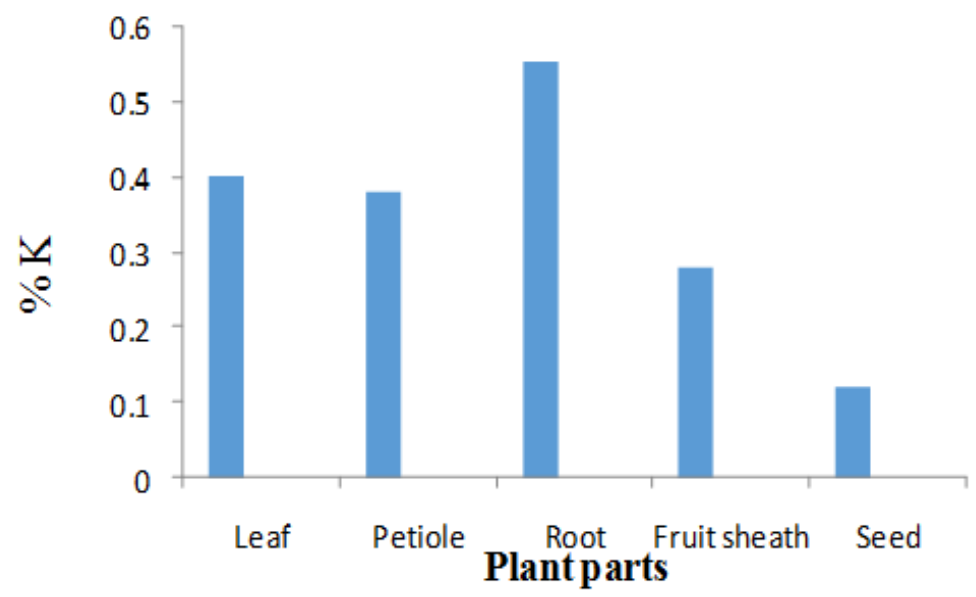


Fig.4 Fe concentrations in different vegetative and seed parts of E. ferox

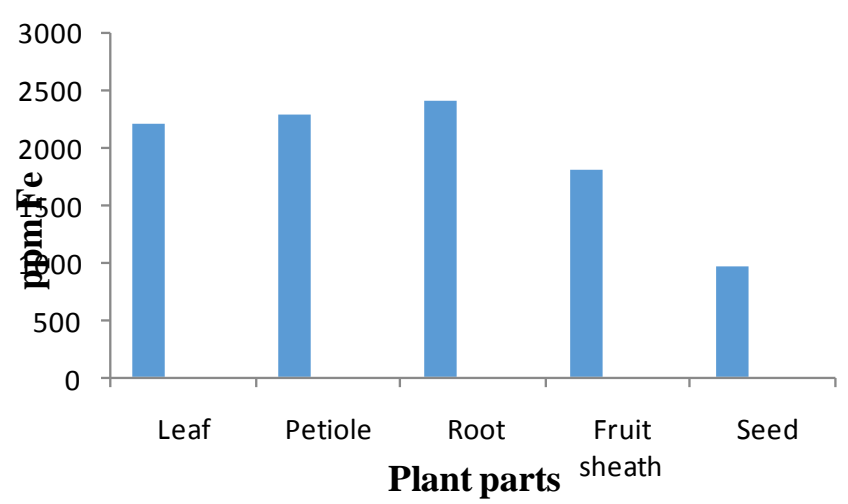

Fig.5 Mn concentrations in different vegetative and seed parts of E. ferox

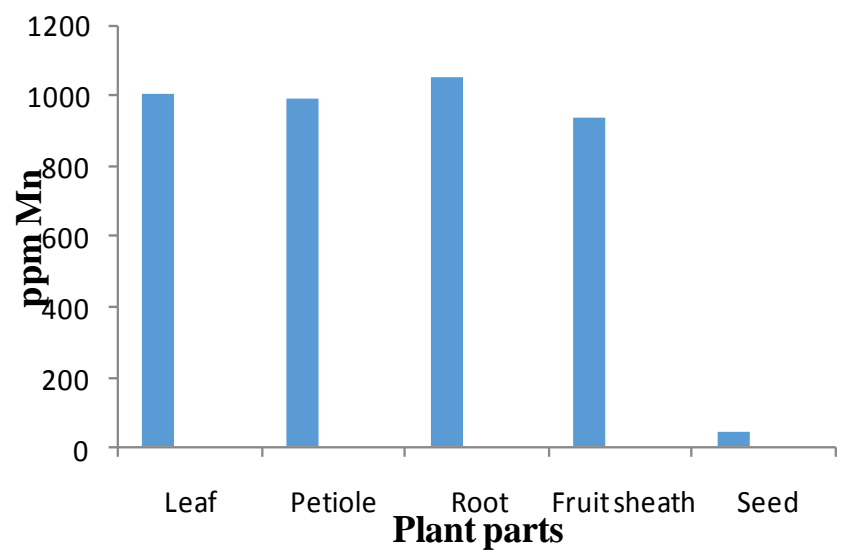

Fig.6 $\mathrm{Cu}$ concentrations in different vegetative and seed parts of $E$. ferox

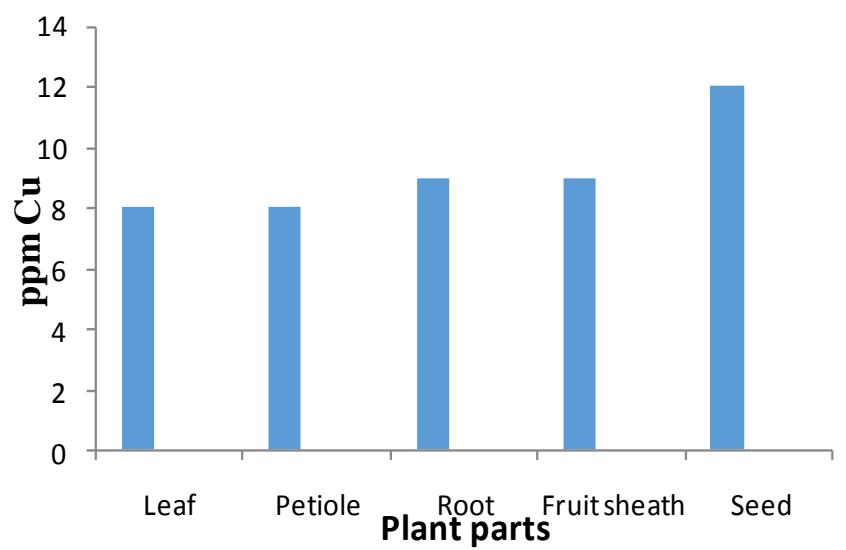


Fig.7 Zn concentrations in different vegetative and seed parts of E. ferox

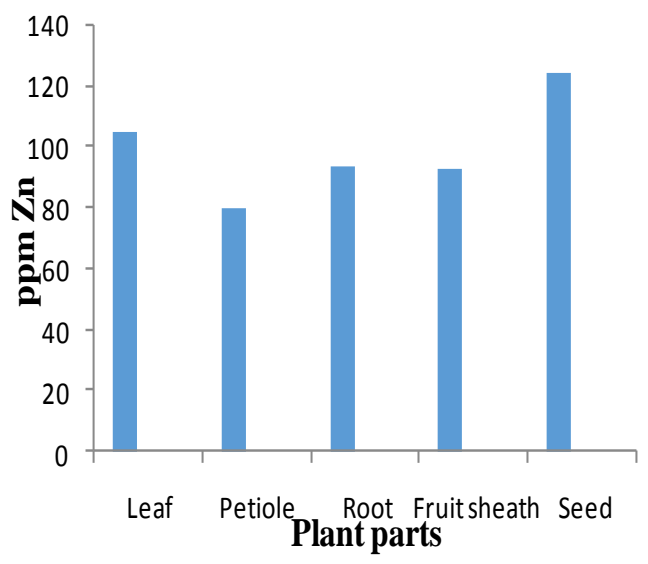

Table.1 Nutrient contribution through E. ferox to the soil (mean values of three years data)

\begin{tabular}{|l|c|c|c|c|c|c|c|}
\hline Plant parts & $\begin{array}{c}\mathrm{N} \\
\mathrm{kg} / \mathrm{ha}\end{array}$ & $\begin{array}{c}\mathrm{P} \\
\mathrm{kg} / \mathrm{ha}\end{array}$ & $\begin{array}{c}\mathrm{K} \\
\mathrm{kg} / \mathrm{ha}\end{array}$ & $\begin{array}{c}\mathrm{Fe} \\
\mathrm{kg} / \mathrm{ha}\end{array}$ & $\begin{array}{c}\mathrm{Mn} \\
\mathrm{kg} / \mathrm{ha}\end{array}$ & $\begin{array}{c}\mathrm{Cu} \\
\mathrm{kg} / \mathrm{ha}\end{array}$ & $\begin{array}{c}\mathrm{Zn} \\
\mathrm{kg} / \mathrm{ha}\end{array}$ \\
\hline Leaf & 14.72 & 22.80 & 19.00 & 10.45 & 4.75 & 0.038 & 0.50 \\
\hline Petiole & 4.05 & 7.77 & 6.42 & 3.85 & 1.67 & 0.01 & 0.13 \\
\hline Root & 11.87 & 16.96 & 23.32 & 10.19 & 4.45 & 0.04 & 0.039 \\
\hline Fruit sheath & 3.71 & 8.51 & 4.33 & 2.77 & 1.44 & 0.01 & 0.14 \\
\hline Seed & 35.07 & 8.40 & 2.52 & 2.016 & 0.08 & 0.02 & 0.26 \\
\hline $\mathrm{CD}(P=0.05)$ & 1.065 & 1.135 & 0.638 & 0.661 & 0.502 & 0.011 & 0.033 \\
\hline
\end{tabular}

Moreover, it is difficult to establish the amount of an element that is transferred from the roots to the shoots.

Trace metal concentration in aquatic plants vary considerably according to the part of the plant as well as to the chemical characteristics of the plants (Baldantoni et al., 2004).

The starch and hard coat of seed have also been proved to be the excellent contributor of macro-elements such as $\mathrm{N}$ and $\mathrm{P}$ as the seeds have been found to accumulate significant amount of $\mathrm{Fe}$ and $\mathrm{Zn}$.

\section{Nutrient contribution through $E$. ferox to} the soil

The importance of E. ferox in relation to improvement of soil fertility has shown that biomass on decomposition adds approximately $34.35,56.04,53.07$ and 27.26 , $12.31 \mathrm{~kg} / \mathrm{ha} \mathrm{N}, \mathrm{P}, \mathrm{K}, \mathrm{Fe}$ and $\mathrm{Mn}$, respectively to the soil (Table 1). The maximum contribution of nutrients has been made by leaf and root organs of E. ferox. These results are in conformity with the findings of Singh et al., (2014) who reported that makhana based cropping system found to be the best cropping system pertaining to the improvement in fertility status of soil. They also reiterated that enrichment of nutrients to the soil system under the Makhana cropping system involving is due to its contribution through addition of an appreciable amount of organic matter (10 t/ha) into the soil on decomposition of the biomass (Kumar et al., 2013). Earlier, Jha and Dutta (2003) also noticed Makhana cropping in natural pond significantly contributed an appreciable quantity of $\mathrm{P}$ and $\mathrm{K}$ to the soil. Singh et al., (2014) found similar results regarding the 
quantity of micronutrients added into the soil due to decomposition of biomass of makhana crop. The removal of $\mathrm{N}, \mathrm{P}, \mathrm{K}, \mathrm{Fe}, \mathrm{Mn}, \mathrm{Cu}$ and $\mathrm{Zn}$ by the seeds from the pond soil has been recorded as 35.07, 8.40, 2.52, 2.016, 0.08, 0.02 and $0.26 \mathrm{~kg} / \mathrm{ha}$, respectively. However, the total uptake of these nutrients made by $E$. ferox was recorded to be $69.42 \mathrm{~kg} / \mathrm{ha} \mathrm{N}, 64.44$ $\mathrm{kg} / \mathrm{ha} \mathrm{P,} 55.59 \mathrm{~kg} / \mathrm{ha} \mathrm{K}, 29.27 \mathrm{~kg} / \mathrm{ha} \mathrm{Fe}$ and $12.39 \mathrm{~kg} / \mathrm{ha} \mathrm{Mn}$. The uptake and removal amount of other nutrients from the soil is very less as it does not take part in effectively affecting the fertility status of soil.

In conclusion, E. ferox grown in shallow wetlands/field condition accumulated substantial amount of $\mathrm{P}, \mathrm{Fe}, \mathrm{Mn}$ and $\mathrm{Zn}$ elements in biomass, which could certainly contribute to removal of these elements from metal contaminated waters and soils. The leaf and root of the plant have been found to be the major contributor of nutrients to the soil. E. ferox tended to have highest tissue concentrations of the less soluble Fe and Mn, with greater concentrations in roots than in shoots. Thus, E. ferox proved a better option as an alternative crop to be included in cropping system mode to replenish the exhausted nutrients such as N, P and Zn by the cultivation of other cereals (rice and wheat). Thus, it greatly helps in sustainable management of natural resources. E. ferox has been identified as one of the most important aquatic crop whose cultivation is highly beneficial for soil-water-plant continuum as it contributes a lot of organic matter to the soil. It also provides most of the nutritionally important essential elements such as $\mathrm{P}, \mathrm{Fe}$ and $\mathrm{Zn}$ in higher quantities as compared with other cereal and leguminous crops.

\section{References}

Baldantoni, D., Alfani, A., Di Tommasi, P., Bartoli, G., De santo, A. (2004) Assessment of macro and microelement accumulation capability of two aquatic plants. Environ. Pollut.130: 149-156.

Bulluck, L.R., Brosius, M., Evanylo, G.K. and Ristaino, J.B. (2002) Organic and synthetic fertility amendments on organic conventional farms. Appl. Soil Ecol., 19: 147-160.

Dutta, R.N. Jha, U.N. and S.N. Jha, (1984) Water quality and soil properties of ponds as influenced by $E$. ferox cultivation. Plant and Soil,80: 441-445.

Dutta, R.N., Jha, U.N. and Jha, S.N. (1986) Relationship of biomass yield of $E$. ferox with soil properties and water quality, Plant and Soil, 95: 345-350.

Jackson, M L. (1973) Soil Chemical Analysis. Prentice Hall of India Pvt. Ltd., New Delhi, 498 pp.

James, E.J. (1995) Managing the wetlands and their watersheds. Yojana, 39 (182): 43-50.

Jha, S.N. and Dutta, R.N. (2003) Soil-Water Chemistry of E. ferox Cultivation. In. Mishra, R.K, Jha, V. and Dehadrai, P.V. (eds). DIPA, ICAR, New Delhi. Pp. 73-84.

Jha, V., Kargupta A. N., Dutta R.N., Jha U.N., Mishra R.K. and Saraswati, K. C. (1991). Utilization and conservation of Euryale ferox Salisb in Mithila (North Bihar), India. Aquatic Bot., 39:295314.

Jha, V., Barat, G.K., and Jha, U.N. (1991) A Nutritional evaluation of Euryale ferox Salisb (Makhana). Journal of food science and Technology. 8 (5):326-328.

Mahto, A., and Jha, V., (1998) Masimizing productivity in the low lying field of Darbhanga (north Bihar, India): A case study of crop rotation between Makhana (Euryale ferox Salisb.) and Wheat (Triticum aestivum) J. fres water Bio. 10(1-2):25-31.

Kumar, L., Gupta, V.K., Jha, B.K., Singh, I.S., Bhatt, B.P. and Singh, A.K. (2011) Status of (Euryale ferox Salisb.) 
Cultivation in India. Tech. Bull. No. R32/PAT-21. ICAR RCER, Patna P. 31.

Kumar, L., Singh, I.S., Gupta, V.K., Bhatt, B.P., Jha, B.K. and Sikka, A.K. (2013) Makhanaki Kheti ki UnnatTakneek. Technical Bulletin Pp. 1-31. Published by ICAR Research Complex for Eatern Region, Patna.

Kumar, R. (2012) Conserving Wetlands in India Prospects and Challenges. News Letter (Sarovar), 1: 6-10, Published by Wetlands International-South Asia, New Delhi

Mitsch, W.J. and Gosselink, J.G. (2000) Wetlands, Third edn., John Willey and Sons, Inc., New York.

Qian, J., Zayed, A., Zhu, Y., Yu, M. and Terry, N. (1999) Phytoaccumulation of trace elements by wetland plants: III. Uptake and accumulation of ten trace elements by twelve plant species. J.Environ. Qual.,28: 1448-1455.

Singh, I.S. (2014). Nutrient contribution by makhana crop to the soil and removal of nutrients by seed parts. Annual Report (2013-14), ICAR RCER, Patnap. 49.
Singh, I.S., Kumar, L., Singh, A.K., Bhatt, B.P. and Singh, S.P. (2014) Impact of makhana, (Euryale ferox Salisb.) based cropping systems on nutrient dynamics of inceptisols of north Bihar. Int. J. Agric. Stat. Sci., 10: 125-129.

Spence, D.H.N. (1964) Themacrophyte vegetation of fresh water lochs, swamps and associated fens. (In): Burnett, J.H. (ed.), The Vegetation of Scotland. Oliver \& Boyd, Edinburgh.

Thomson, C.J., Atwell, B.J., Greenway, H. (1989) Response of wheat seedlings to low $\mathrm{O}_{2}$ concentrations in nutrient solution: $\mathrm{II} \mathrm{K} / \mathrm{Na}^{+}$selectivity of tissues of different age. J. Exp. Bot.,40: 993999.

Ye, Z., Whiting, S.N., Lin, Z.Q., Lytle, C.M., Qian, J.H. and Terry, N. (2001) Removal and distribution of iron, manganese, cobalt and nickel within a Pennsylvania constructed wetland treating coal combustion by product leachate. J. Environ. Qual., 30: 14641473.

\section{How to cite this article:}

Amit Kumar, I.S. Singh, A.K. Thakur, A.K. Choudhary, Vidyanath Jha, S.P. Singh, S.S. Prasad, Pankaj Yadav and Ramesh Kumar. 2017. Bioaccumulation of Plant Nutrients by Euryale ferox Salisb. Growing in Field Condition in Northern Bihar of North India. Int.J.Curr.Microbiol.App.Sci. 6(7): 1229-1237. doi: https://doi.org/10.20546/ijcmas.2017.607.148 